
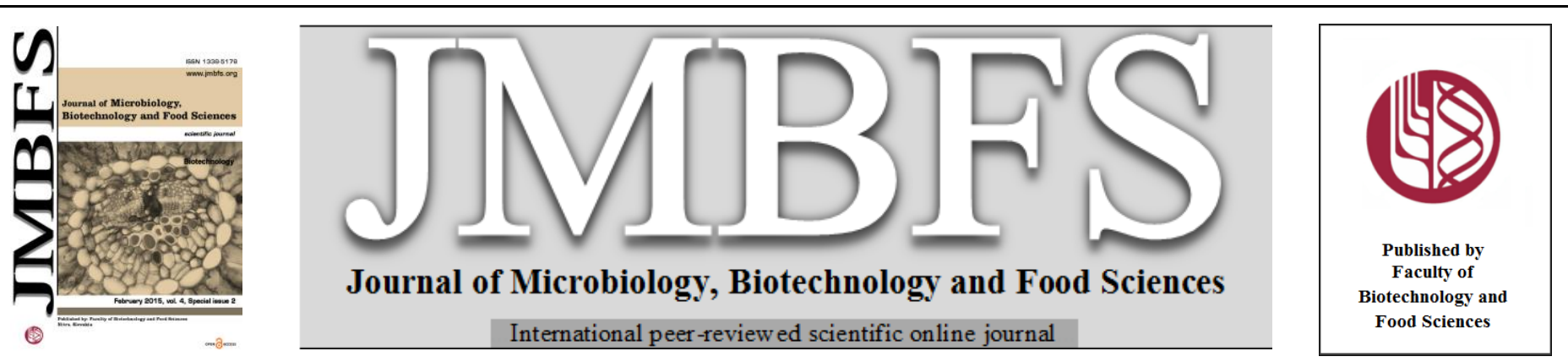

\title{
WHEAT PATHOGEN RESISTANCE AND CHITINASE PROFILE
}

\section{Zuzana Gregorová ${ }^{1}$, Peter Socha ${ }^{2}$, Marína Maglovski ${ }^{3}$, Jana Moravčiková ${ }^{3}$, Jana Libantová ${ }^{3}$, Roman Kuna $^{1}$, Pavol Hauptvogel ${ }^{4}$ Matušíková Ildikó*3}

\section{$\operatorname{Address(es):~}$}

${ }^{1}$ Department of Botany and Genetics, Faculty of Natural Sciences, Constantine the Philosopher University in Nitra, Nábrežie mládeže 91,94974 Nitra, Slovakia, zuzana.gregorova@ukf.sk

${ }^{2}$ Department of Biochemistry and Biotechnology, Faculty of Biotechnology and Food Sciences, Slovak University of Agriculture in Nitra, Tr. A. Hlinku 2, 94976 Nitra, Slovakia, socha@uniag.sk

${ }^{3}$ Institute of Plant Genetics and Biotechnology, Slovak Academy of Sciences, Akademická 2, 95007 Nitra, Slovakia, ildiko.matusikova@savba.sk

${ }^{4}$ National Agricultural and Food Centre, Research Institute of Plant Production, Bratislavská cesta 122, 92168 Pieštany, Slovakia, hauptvogel@ vurv.sk

*Corresponding author: ildiko.matusikova@ savba.sk

doi: 10.15414/jmbfs.2015.4.special2.15-18

\section{ARTICLE INFO}

Received 8. 12. 2014

Revised 18. 12. 2014

Accepted 5. 1. 2015

Published 2. 2. 2015

\section{Regular article} open 2 ACcess

\section{INTRODUCTION}

Wheat (Triticum aestivum and Triticum spelta $-\mathrm{AABBDD}, 2 \mathrm{n}=42$ ) is the mos widely grown crop plant, occupying $17 \%$ of all the cultivated land (Gill et al., 2004). Biotic and abiotic stresses are important limiting factors for yield quality in wheat production. Powdery mildew caused by obligate biotrophic fungus Blumeria graminis f.sp. tritici (Bgt), is one of the most devastating diseases of wheat, that causes significant yield losses. Well known are also rust diseases of wheat, the most common leaf or brown rust is caused by the fungus Puccinia recondita f.sp. tritici. Leaf rust produces orange-brown uredinia (fruiting bodies) in pustules primarily on the upper surface of leaves. Heavy rusting causes early loss of infected leaves (Griffey et al., 1993).

To reduce the damage caused by biotic factors, plants have evolved many sophisticated adaptive response mechanisms. A plant-pathogen interaction may therefore be considered as an open warfare, of which major weapons are protein and low-molecular-mass compounds synthesized/accumulated by both organisms (Ferreira et al.,2007). Inducible defence mechanisms mainly involve synthesis of pathogenesis-related (PR) proteins including chitinases (PR-3 group)

Chitinases (EC 3.2.1.14) constitute the second largest group of antifunga proteins (Kasprzewska, 2003) and are glucanhydolases that catalyze the hydrolysis of chitin. Since this polymer of unbranched $\beta$-1,4-linked 2-acetamido2-deoxyD-glucose is absent in plants, but present in many fungal pathogens, the role of these enzymes in plants has primarily been established in defense responses against (mainly fungal) pathogen (Meins et al. 1989, Van Loon et al., 2006). Massive induction of chitinases has been described in many plant species against various microorganisms, but important role under abiotic stress (e.g. metals, drought, heat etc.) has also been described (Mészáros et al., 2013) Moreover, specific chitinase isoforms appear to play role in normal plant growth and development (Regalado et al., 2000). Chitinases, as with many other PR proteins, may be synthesized in both a constitutive and an inducible manner. In this work, the profile and overall activity of chitinase enzymes was studied in selected set of bread wheat (Triticum aestivum) and spelt wheat (Triticum spelt). The data were compared between the individual hexaploid wheat types. Further, since conventional assays of chitinase activities revealed correlation with sensitivity to biotic as well as abiotic stresses, we traced the correlation of chitinase enzyme activity in wheat accessions with available data on resistance to selected diseases. Chitinases once proven as reliable molecular markers might be very helpful for traditional plant breeding approaches in efforts to identify tolerant varieties.

\section{MATERIAL AND METHODS}

\section{Plant material and growth conditions}

The set of 8 wheat genotypes from species T. aestivum and T. spelta of different origin was used (Table 1). The collection was provided by Gene Bank in Plan Production Research Center, Piešt'any (Slovakia). Wheat seeds were germinated in Petri dishes lined with two layers of water-moistened filter paper (Whatman No. 1) in cultivation room at $25^{\circ} \mathrm{C}$ and daily length of 16 hours for $6-7$ days. For analyses young wheat leaves were used.

\section{Chitinase quantitative assay}

A fluorimetric assay was used to detect endochitinase activity in crude protein extracts using the synthetic substrate 4-methylumbelliferyl- $\beta$-D-N,N',N"' triacetylchitotrioside [4-MU-(GlcNAc)3] (Sigma, USA) as described previously (Libantova et al., 2009). The reaction mixture contained $20 \mu \mathrm{l}$ of protein extracts mixed with $30 \mu$ of $300 \mu \mathrm{M}$ substrate in $0.1 \mathrm{M}$ sodium citrate buffer $(\mathrm{pH} 3.0$ ). The assay was carried out in 96 -well black-sides assay plates. After incubation at $37^{\circ} \mathrm{C}$ for $1 \mathrm{~h}$, the reaction was stopped by adding $150 \mu \mathrm{l}$ of $0.2 \mathrm{M} \mathrm{Na}_{2} \mathrm{CO}_{3}$ and fluorescence was measured by Fluoroskan II microtiterplate reader (TITERTEK, Finland) using excitation and emission filters $355 \mathrm{~nm} / 450 \mathrm{~nm}$ (Cohen et al, 2006). Based on the standard curve, the chitinase activity was calculated as picomoles of methylumbelliferone (4-MU) generated per hour per microgram of soluble protein.

\section{Detection of chitinases activity in gel}

Total proteins were extracted from young leaves according to Hurkman and Tanaka (1986), and their concentration was determined by Bradford (1976). Separation of proteins (aliquots of $20 \mu \mathrm{g}$ ) on $1.0 \mathrm{~mm}$ thick minigels was done using Mini-PROTEAN Tetra Cell apparatus (Bio-Rad laboratories, USA) according to Laemmli (1970). The $0.01 \%$ (w/v) glycol chitin obtained by acetylation of glycol chitosan (Sigma, USA) (Trudel and Asselin, 1989) was used as a substrate for chitinases and was added directly into $12.5 \%$ polyacrylamide 
gels. Molecular weights of proteins were estimated using protein ladder (Mark 12 Unstained Standard, Invitrogen). Electrophoretic conditions during separation of proteins were $18 \mathrm{~mA}$ in stacking gel and $24 \mathrm{~mA}$ in separation gel under constant current for cca. 3-4 h. After electrophoresis, proteins were re-natured by shaking the gels in $50 \mathrm{mM}$ sodium acetate buffer ( $\mathrm{pH} 5.0)$ containing $1 \%(\mathrm{v} / \mathrm{v})$ Trition $\mathrm{X}$ 100 overnight. The chitinase profile was detected according to Pan et al. (1991) upon staining with $0.01 \%$ (w/v) Fluorescent Brightener 28 (Sigma, USA) in 250 $\mathrm{mM}$ Tris- $\mathrm{HCl}(\mathrm{pH}$ 8.9) for $15 \mathrm{~min}$, and subsequently visualized under UV light using UVP Bio Doc-It System. The active chitinases appeared as dark bands on a bright background. The gels were photographed and contrast was adjusted using Scion Image software (http://www.scioncorp.com). After detection of chitinases, the gels were stained for detection of total proteins with $5 \%(\mathrm{w} / \mathrm{v})$ Coomassie Brilliant Blue R-250 in $7 \%(\mathrm{v} / \mathrm{v})$ acetic acid and $20 \%(\mathrm{v} / \mathrm{v})$ methanol, and photographed again

\section{Evaluation of descriptors}

For evaluation of wheat resistance to fungal pathogens, descriptor list for genus Triticum L. available at Gene Bank in Plant Production Research Centre, Piešt’any (Slovakia), was used for plants grown in years 2010, 2011 and 2012 According to this descriptor, degree of disease/pests resistance is based on the scale from low (0) to high (10) degree of resistance. Leaf and spike powdery mildew (Blumeria graminis f.sp. tritici) and brown rust (Puccinia recondita f.sp tritici) was chosen as most common wheat fungal pathogens.

\section{RESULT AND DISCUSSION}

Generally, selected cultivars of Triticum aestivum were less resistant to leaf and spike powdery mildew (Blumeria graminis f.sp. tritici) and brown rust (Puccinia recondita f.sp. tritici) comparing to cultivars of Triticum spelta (Tab. 1).

Table 1 Data on disease resistance in studied wheat accessions

\begin{tabular}{|c|c|c|c|c|}
\hline & \multirow[t]{2}{*}{ Wheat variety } & \multicolumn{2}{|c|}{ Powdery mildew ${ }^{a}$} & \multirow[t]{2}{*}{ Leaf rust ${ }^{a}$} \\
\hline & & leaf & spike & \\
\hline \multirow{4}{*}{ Triticum aestivum } & 1 - Astella & medium & medium & medium \\
\hline & 2 - Radošinska Norma & low & low & low \\
\hline & 3 - Šamorínska & low & low & low \\
\hline & 4 - Vígl’ašská Červenoklasá & low & low & low \\
\hline \multirow{4}{*}{ Triticum spelta } & 5 - Epeautre Nain & medium & medium & low \\
\hline & 6 - Kipperhaus Wiesser Spelz 3/2 & low & high & medium \\
\hline & 7 - Spelt, Lad Grasort 1/9 & medium & medium & medium \\
\hline & 8 - White Spelt & medium & medium & medium \\
\hline
\end{tabular}

Disease resistance based on 3-year field experiments

In the experimental plants the total chitinase activities were measured fluorimetrically (Fig. 1). No differences between chtiinase activities of Triticum aestivum and Triticum spelta representatives were noticed. Further, the obtained data show that degree of disease resistance does not correlate with total chitinase activity in wheat tissue (Fig. 1).

A

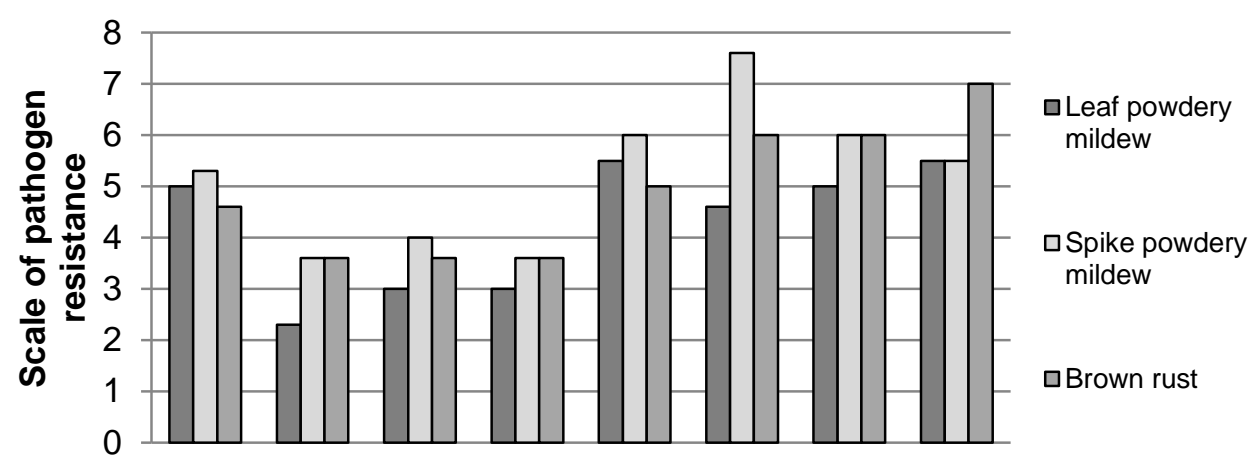

B

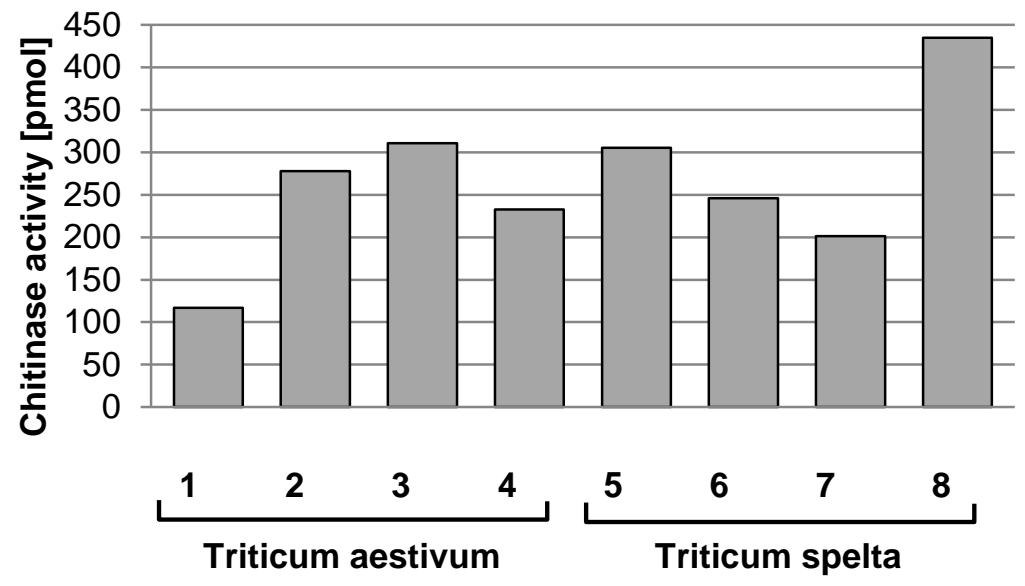

Figure 1 Representatives of bread wheat (Triticum aestivum) (1-4) and spelt wheat (Triticum spelta) (5-8) are differently sensitive to various fungal diseases (A/upper graph).

The cultivars were analyzed for activity of chitinases in leaf tissue (B/lower graph). The data show no sound interaction between resistance against pathogens and chitinase activity in different wheat cultivars. The individual wheat cultivars 1-8 are listed in Table 1 .
The overall enzyme activity of chitinase in plant tissue, however, not necessarily reflects the behaviour of individual isoforms, especially under changing environmental conditions (Piršelová et al., 2011). For this reason, studying the behaviour of chitinase fractions after separation in gels might be more informative. Previously, existence of multiple intercellular chitinase isoenzymes were detected in wheat plants under non-denaturing conditions. In wheat, $50 \%$ of 
the chitinase isoenzymes were found in the basic fractions and the other $50 \%$ was located in acidic fractions (Botha et al., 1998). Moreover, chitinases can be synthesized both constitutively as well as in inducible manner (Ferreira et al., 2007).
In the eight tested wheat cultivars we studied and compared the pattern of chitinases as typical plant defense molecules. Our study had identified four chitinase isoforms with different sizes of $40 \mathrm{kDa}, 35 \mathrm{kDa}, 25 \mathrm{kDa}$ and $20 \mathrm{kDa}$ in all wheat plants (Fig. 2).

\section{Total proteins}

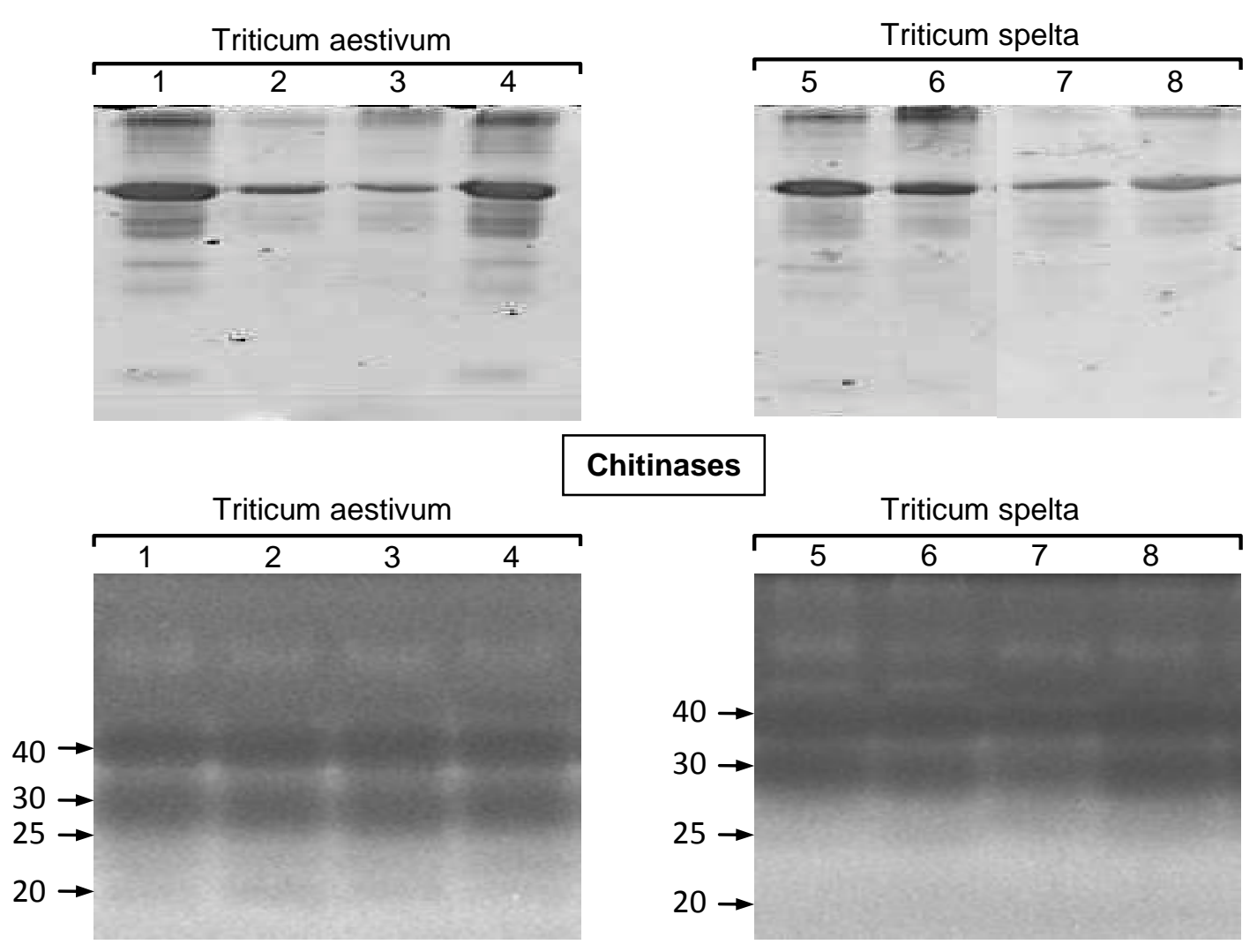

Figure 2 Chitinase pattern in representatives of bread wheat (Triticum aestivum) and spelt wheat (Triticum spelta). Proteins were separated on glycol chitin containing gels using SDS-PAGE. Subsequently gels were stained for chitinase activities with Fluorescent Brigthener 28 and visualised under UV-light. Arrows indicate the molecular mass of corresponding protein bands in $\mathrm{kDa}$.

Other authors have observed similar profiles in their studies. However, while in susceptible plants five different chitinase activity peaks were detected, in the resistant counterparts there were six activity peaks identified (Sahai and Manocha, 1993). The resistant and susceptible plants differ in the presence of two acidic isoenzymes (Botha et al., 1998). Furthermore, after different plant treatments (e.g. pathogen attack, ethylene treatment) the number of chitinase isoforms increased, while still higher number was present in the resistant variety. Additive isoforms might be indicators for better defense equipment against fungi. Previously, a chitinase $(30.8 \mathrm{kDa})$ with antifungal activity has been isolated from mung bean (Phaseolus mungo) seeds (Wang et al., 2005), whereas two 28-kDa chitinases designated chitinase A and chitinase B also exhibiting antifungal activity were characterized in maize (Zea mays) seeds (Huynh et al., 1992). For comparison, 8 chitinase isoforms were identified in tobacco (Pan et al., 1992), 3 chitinase isoforms in cucumber (Zhang and Punja 1994). In celery, two chitinases were strongly induced by fungi (Krebs and Grumet 1991). Temporally affected expression profiles (with maxima after 36-72 hpi) were observed for two endochitinases in wheat upon infection of wheat-Fusarium, yellow dwarf virus (YDV) and Hessian fly (Wu et al., 2013). Previously, similar amplitudes of expression for two different chitinase genes were detected in a susceptible- and sensitive wheat cultivars ( $\mathrm{Li}$ et al., 2001). Kinetics not only amplitude of chitinase induction might be crucial for efficient defense against stress (Mészáros et al., 2013), since fast response can affect the outcome of plant-pathogen interaction in favour of plant. Nevertheless our results showed that the basic pattern of chitinases is not a reliable indicator of pathogen resistance (susceptibility). Similar study on plants exposed to pathogen infection might reveal such markers of cultivars with good/bad defense equipment.

\section{CONCLUSION}

In conclusion, we have found that tested bread wheat cultivars are less resistant to common wheat fungi as well as powdery mildew and brown rust comparing with the analysed representatives of spelt wheat. The cultivars also differ in the overall chitinase activity in leaf tissue. However, there is no sound correlation between chitinase activity and level of resistance. In each wheat cultivar up to four chitinase isoforms with different size were detected. Studying these profiles upon pathogen infection might reveal isoforms that are inducible during abiotic stress and/or can be evaluated as markers of overall resistance/susceptibility.

Acknowledgments: This work was supported by the Slovak Research and Development Agency under the contract No. APVV-0197-10, VEGA 1/0509/12, UGA VII/5/2014 and UGA VII/61/2013.

\section{REFERENCES}

BOTHA, A-M, NAGEL, M. A. C., Van der Westhuizen, A. J., BOTHA, F. C. 1998. Russian wheat aphid infestation, exogenous ethylene, mechanica wounding, and chitinase isoenzymes. Botanical Bulletin of Academia Sinica, 39, 99-106.

BRADFORD, M. M. 1976. A rapid and sensitive method for the quantitation of microgram quantities of protein utilizing the principle of protein-dye binding. Analytical Biochemistry, 72,248-254. http://dx.doi.org/10.1016/00032697(76)90527-3

COHEN, S., SCHUSTER, S., MOVTCHAN, A., ZILBERSTEIN, A. 2006 Isolation and characterization of chitinase of the carnivorous plant Nepenthes khasiana. Journal of Experimental Botany. 57(11), 2775-2784. http://dx.doi.org/10.1093/jxb/er1048

FERREIRA, R., MONTEIRO, S., FREITAS, R., SANTOS, C. N., CHEN, Z., BATISTA, L. M., DUARTE, J., BORGES, A. TEXTEIRA, A. R. 2007. The role of plant defense proteins in fungal pathogenes. Molecular Plant Pathology. 8(5), 677-700. http://dx.doi.org/10.1111/j.1364-3703.2007.00419.x

GILL, B. S., APPELS, R., BOTHA-OBERHOLSTER, A. M., BUELL, C. R., BENNETZEN, J. L., CHALHOUB, B., CHUMLEY, F., DVORAK, J., IWANAGA, M., KELLER, B., LI, W., McCOMBIE, W. R., OGIHARA, Y., QUETIER, F.2004. A workshop report on wheat genome sequencing: 
International Genome Research on Wheat Consortium. Genetics, 168, 10871096. http://dx.doi.org/10.1534/genetics.104.034769

GRIFFEY, C. A, DAS, M. K., STROMBERG, E. L. 1993. Effectiveness of adult-plant resistance in reducing grain yield loss to powdery mildew in winter wheat. Plant Disease, 77, 618-622.

HURKMAN, W. J., TANAKA, C. K.. 1986. Solubilization of plant membrane proteins for analysis by two-dimensional gel electrophoresis. Plant Physiology, 81(3), 802-806. http://dx.doi.org/10.1104/pp.81.3.802

HUYNH, Q. K., HIRONAKA, C. M., LEVINE, E. B., SMITH, C. E., BORGMEYER, J. R., SHAH, D. M. 1992. Antifungal proteins from plants. Purification, molecular cloning, and antifungal properties of chitinases from maize seed. Jornal of Biological Chemistry, 267, 6635-6640.

KASPRZEWSKA, A. 2003 Plant chitinases-regulation and function. Cellular and Mollecularm Biology Letters, 8, 809-824.

KREBS, S. L., GRUMET, R. 1993. Characterization of celery hydrolytic enzymes induced in response to infection by Fusarium oxysporum. Physiological and Molecular Plant Pathology, 43(3), 193-208. http://dx.doi.org/10.1006/pmpp.1993.1050

LAEMMLI, U. K. 1970. Cleavage of structural proteins during the assembly of the head of bacteriophage T4. Nature, 227(5259), 680-685.

LI, W. L., FARIS, J. D., MUTHUIKRISHNAN, S., LIU, D. J., CHEN, P.D., GILL, B. S. 2001. Isolation and characterization of novel cDNA clones of acidic chitinases and $\beta-1,3$-glucanases from wheat spikes infected by Fusarium graminearum. Theoretical and Applied Genetics, 102, 352-362.

LIBANTOVA, J., KAMARAINEN, T., MORAVCIKOVA, J., MATUSIKOVA, I., SALAJ, J. 2009. Detection of chitinolytic enzymes with different substrate specificity in tissues of intact sundew (Drosera rotundifolia L.). Molecular Biology Reports, 36, 851-856. http://dx.doi.org/10.1007/s11033-008-9254-z

MEINS F., AHL P. 1989. Induction of chitinase and $\beta$-1,3-glucanase in tobacco plants infected with Pseudomonas tabaci and Phytophthora parasitica var Nicotianae. Plant Science, 61(2), 155-161. http://dx.doi.org/10.1016/01689452(89)90219-7

MÉSZÁROS, P., RYBANSKÝ, L', HAUPTVOGEL, P., KUNA, R., LIBANTOVÁ, J., MORAVČÍKOVÁ, J., PIRŠELOVÁ, B., TIRPÁKOVÁ, A. MATUŠÍKOVÁ, I. 2013. Cultivar-specific kinetics of chitinase induction in soybean roots during exposure to arsenic. Molecular Biology Reports, 40(3), 2127-2138. http://dx.doi.org/10.1007/s11033-012-2271-y

PAN, S. Q., YE, X. S., KUC, J. 1991. A technique for detection of chitinase, beta-1,3-glucanase, and protein- patterns after a single separation using polyacrylamide-gel electrophoresis or isolelectrofocusing. Phytopathology, 81(9), 970-974.

PAN, S. Q., YE, X. S:, KUC, J. 1992. Induction of chitinases in tobacco plants systemically protected against blue mold by Peronospora tabacina or tobacco mosaic virus. Phytopathology, 82(1), 119-123. http://dx.doi.org/10.1094/Phyto$\underline{82-119}$

PIRŠELOVÁ, B., MATUŠÍKOVÁ, I. 2011. Plant defense against heavy metals: the involvement of pathogenesis - related (PR) proteins. Studium Press LLC, 179-205 p. ISBN 1-933699-21-3.

REGALADO, A. P., PINHEIRO, C. VIDAL, S., CHAVES, I., RICARDO, C. P. P., RODRIGUES-POUSADAL, C. 2000. The Lupinus albus class-III chitinase gene, IF3, is constitutively expressed in vegetative organs and developing seeds. Planta. 210, 543-550. http://dx.doi.org/10.1007/s004250050043

SAHAI, A. S., MANOCHA, M. S. 1993. Chitinases of fungi and plants: their involvement in morphogenesis and host-parasite interaction. FEMS Microbiology Reviews, 11(4), 317-338.

TRUDEL, J., ASSELIN, A. 1989. Detection of chitinase activity after polyacrylamide gel electrophoresis. Analytical Biochemistry, 178(2), 362-366. http://dx.doi.org/10.1016/0003-2697(89)90653-2

Van LOON, L. C., REP, M., PIETERSE, C. M. J. 2006. Significance of Inducible Defense-related Proteins in Infected Plants. Annual Review of Phytopathology, 44: 135-162. http://dx.doi.org/10.1146/annurev.phyto.44.070505.143425

WANG, S., WU, J., RAO, P., NG, T. B. 2005. A chitinase with antifungal activity from the mung bean. Protein Expression and Purification, 40, 230-236. http://dx.doi.org/10.1016/j.pep.2004.06.032

WU, Q., BAI, L., LIU, W., LI, Y., LU, C., LI, Y., FU, K., YU, Ch., CHEN, J. 2013. Construction of a Streptomyces lydicus A01 transformant with a chit42 gene from Trichoderma harzianum P1 and evaluation of its biocontrol activity against Botrytis cinerea. Journal of Microbiology, 51(2), 166-173. http://dx.doi.org/10.1007/s12275-013-2321-8

ZHANG, Y-Y, PUNJA, Z. K. 1994. Induction and characterization of chitinase isoforms in cucumber (Cucumis sativus L.): effect of elicitors, wounding and pathogen inoculation. Plant Science, 99(2), 141-150. http://dx.doi.org/10.1016/0168-9452(94)90171-6 